\title{
Menciptakan Calon Perwira Kapal Penangkap Ikan Bertaraf Internasional Melalui Sertifikasi Profesi Calon Pelaut yang Handal dan Berdedikasi Tinggi serta Berbudaya Indonesia Untuk Alumni Taruna SMK Kemaritiman Bangka Belitung
}

\author{
Helmi Ibrahim, S.Pd.
}

\begin{abstract}
This article aims to mobilize and unite the steps of stakeholders to create prospective fishing vessels, especially maritime vocational cadets where the existence of SMKN 4 Pangkalpinang, SMKN 2 Sungailiat, and SMKN 1 Tukak Sadai under the auspices of the Provincial Bangka Belitung Islands Education Office and Maritime Affairs and Fishery. This research is a correlative descriptive study so that the data is analyzed to determine the relationship between Vocational High Schools maritime cadets and the Government of the Bangka Belitung Islands which is very closely related to the success of vocational education to produce potential fishing vessel officers. The instrument for data collection uses documentation, questionnaires, and direct observations which are then analyzed using simple linear correlation. The results obtained were government policies in providing overall support in developing Maritime Vocational High Schools in the Bangka Belitung Islands Province including laboratory facilities (SMKN 4 Pangkalpinang : 80\%, SMKN 2 Sungailiat : 45\%, SMKN 1 Tukak Sadai : 45\%), Infrastructure practice tools (SMKN 4 Pangkalpinang : 75\%, SMKN 2 Sungailiat: 50\%, SMKN 1 Tukak Sadai : 30\%), Simulator (SMKN 4 Pangkalpinang : 50\%, SMKN 2 Sungailiat : 100\%, SMKN 1 Tukak Sadai : 0\%), Ships (SMK 4 Pangkalpinang: 100\%, SMKN 2 Sungailiat : 100\%, SMKN 1 Tukak Sadai : 50\%).
\end{abstract}

Keywords : Candidates Officer Fishing Vessel, the Provincial Government Islands Bangka Belitung, and Maritime Cadets.

\section{ABSTRAK}

Artikel ini bertujuan untuk menggerakkan dan menyatukan langkah para stakeholder untuk menciptakan calon perwira kapal penangkap ikan khususnya Taruna SMK Kemaritiman yang mana keberadaan SMKN 4 Pangkalpinang, SMKN 2 Sungailiat, dan SMKN 1 Tukak Sadai yang dibawah naungan Dinas Pendidikan Provinsi Kepulauan Bangka Belitung dengan Bidang Kemaritiman dan Perikanan. Penilitian ini merupakan penelitian deskriptif korelatif sehingga data dianalisis untuk mengetahui hubungan antara taruna SMK Kemaritiman dengan Pemerintahan Kepulauan Bangka Belitung yang sangat berhubungan erat dengan keberhasilan pendidikan kejuruan menghasilkan calon perwira kapal penangkap ikan. Instrumen pengambilan data menggunakan dokumentasi, angket, dan pengamatan langsung yang kemudian dianalisis menggunakan korelasi linier sederhana. Hasil penelitian diperoleh adalah kebijakan pemerintah dalam memberikan dukungan secara menyeluruh dalam mengembangkan SMK Kemaritiman yang ada di Provinsi Kepulauan Bangka Belitung meliputi sarana laboratorium (SMKN 4 Pangkalpinang : 80\%, SMKN 2 Sungailiat : 45\%, SMKN 1 Tukak Sadai: 45\%), Prasarana alat praktek (SMKN 4 Pangkalpinang: 75\%, SMKN 2 Sungailiat : 50\%, SMKN 1 Tukak Sadai: 30\%), Simulator (SMKN 4 Pangkalpinang : 50\%, SMKN 2 Sungailiat : 100\%, SMKN 1 Tukak Sadai : 0\%), Kapal (SMKN 4 Pangkalpinang : 100\%, SMKN 2 Sungailiat : 100\%, SMKN 1 Tukak Sadai : 50\%).

Kata Kunci : Calon Perwira Kapal Penangkap Ikan, Pemerintah Provinsi Kepulauan Bangka Belitung, dan Taruna Kemaritiman. 


\section{PENDAHULUAN}

\section{A. Latar Belakang}

Pulau Bangka terletak di Pesisir Timur Pulau Sumatera dengan luas $11.693,54 \mathrm{~km}^{2}$, berbatasan laut Natuna dan Laut Cina Selatan di sebelah Utara, selat Gaspar, selat Karimata dan pulau Belitung di sebelah timur, laut Jawa di sebelah selatan, Selat Bangka dan Pantai Timur pulau Sumatera di sebelah barat. Posisi Pulau Bangka memanjang dari barat laut ke tenggara sepanjang hampir $180 \mathrm{~km}$ berbentuk mirip seperti binatang kuda laut (Hippocampus bargibanti) (Ahmad Elvian, ... :1).

Potensi yang sangat kaya pada Provinsi Kepulauan Bangka Belitung adalah luas daratan yang dikelilingi oleh perairan dengan perbandingan daratan dan lautan yang sangat dominan dan memiliki potensi mata pencaharian dan tempat berwisata. Kalau kita lihat potensi ini sangatlah prihatin,jika kita tidak dapat memanfaatkan secara maksimal potensi yang tersebar di provinsi yang tercinta ini baik sumberdaya manusianya dan sumberdaya alamnya. Sebagai salah satu alur pelayaran, perkembangan perdagangan, dan tumbuhnya industri yang bergerak dibidang kemaritiman sangat pesat dan selalu membutuhkan sumberdaya manusia yang handal, kreatif, inovatif, dan tentunya harus memiliki kompetensi/life skill yang sesuai dengan latar belakang pendidikannya. Sumberdaya manusia ini dapat diperoleh melalui institusi akademik, salah satu jawaban sederhana adalah Provinsi Kepulauan Bangka Belitung sudah memiliki sekolah kejuruan yang sesuai dengan karakter kemaritiman dan perikanan yaitu :

1. SMKN 4 Pangkalpinang, yang terletak di Jl. Pasir Ketapang, Kel. Tamberan Kec. Bukit Intan, Kota Pangkalpinang.

2. SMKN 2 Sungai Liat Bangka, yang terletak di Jl. Sinar Baru, Sungailiat, Kabupaten Bangka.

3. SMKN 1 Tukak Sadai, Jl. Desa Tukak, Kabupaten Bangka Selatan.

Antusias orangtua untuk mendaftarkan anaknya sebagai peserta didik terhadap sekolah tersebut sangat cukup besar, untuk menjadi seorang pelaut yang mumpuni sesuai dengan aturan ketenagakerjaan dibawah naungan Internasional Maritime Organization (IMO) yang diteruskan dengan amendemen STCW (Standarts of Training Certificates Watch Keeping)tahun 1978 diratifikasi Pada 7 Juli Tahun 1995 dan Amandemen Manila Tahun 2010diperkuat dengan Keputusan Menteri Perhubungan Nomor 9 Tahun 2005 tentang Pendidikan dan Pelatihan, Ujian Serta Sertifikasi Pelaut Kapal Penangkap Ikan (Ilham Dwi Putra, 2010).

http://alhamdulillahyahse.wixsite.com/ilham dwiputra/single-post/2016/02/17/STCWManila-Amandemen-2010 
Sisi lain penyerapan tenaga kerja pada dunia industri pelayaran perikanan masih banyak belum terdata, tertata dan terlebih lagi minimnya para alumni dari beberapa sekolah kejuruan pelayaran yang memiliki sertifikat pelaut sesuai Keputusan Menteri Perhubungan Nomor 9 Tahun 2005 dibawah naungan Dewan Penguji Kompetensi Pelaut (DPKP) Direktorat Jenderal Perhubungan Laut-Indonesia.

\section{METODE PENELITIAN}

A. Waktu dan tempat penelitian.

1. Waktu Penelitian

Rentang waktu penelitian dilaksanakan mulai bulan 3 Agustus sampai dengan 3 September 2018, dengan pengumpulan data secara kunjungan ke beberapa sekolah kemaritiman dan dinas terkait, diantaranya ; Dinas Pendidikan, Dinas Kelautan dan Perikanan, Dinas Tenaga Kerja, dan Badan Pusat Statistik (BPS), Dinas Perhubungan Provinsi Kepulauan Bangka Belitung.

2. Tempat Penelitian

Untuk mendapatkan data yang valid, penulis mengunjungi beberapa sekolah kemaritiman dengan Jurusan Nautika Kapal Penangkap Ikan (NKPI) diantaranya sebagai berikut :

a. SMKN 4 Pangkalpinang sebagai tempat penulis bertugas.

b. SMKN 2 Sungai Liat, Sinar Baru, Kabupaten Bangka.

c. SMKN 1 Tukak Sadai, Desa Tukak, Kabupaten Bangka Selatan.

Dapat dilihat dari tabel waktu dan tempat penelitian penulis dalammenyusun dan menyelesaikan makalah ilmiah tersebut, yaitu :

Tabel. 2.1 Waktu dan Tempat Penelitian

\begin{tabular}{|c|c|c|c|c|}
\hline \multirow{3}{*}{$\begin{array}{c}\text { No. } \\
1\end{array}$} & \multirow{3}{*}{ Jenis Kegiatan } & \multicolumn{3}{|c|}{ Tahun 2018} \\
\hline & & Agustus & September & Oktober \\
\hline & & & & \\
\hline 2 & $\begin{array}{llll}\text { Pengumpulan data } & \text { SMKN } & 4 \\
\text { Pangkalpinang } & & & \\
\end{array}$ & & & \\
\hline 3 & $\begin{array}{llll}\begin{array}{l}\text { Pengumpulan data } \\
\text { Sungailiat }\end{array} & \text { SMKN } 2 \\
\end{array}$ & & & \\
\hline 4 & $\begin{array}{llll}\text { Pengumpulan } & \text { data } & \text { SMKN } & 1 \\
\text { Tukak Sadai } & & & \end{array}$ & & & \\
\hline 5 & Analisa Data & & & \\
\hline 6 & Penyusunan dan Penyelesaian & & & \\
\hline 7 & Seminar & & & \\
\hline
\end{tabular}

Sumber: HasilPengolahan Data OlehPenelitiTahun 2018. 


\section{B. Subjek Penelitian}

Subjek penelitian ini adalah warga sekolah kemaritiman yang berada di Provinsi Kepulauan Bangka Belitung.

\section{Objek Penelitian}

Objek penelitian pada penulisan makalah ini adalah terciptanya calon perwira baru di atas kapal Perikanan dan Niaga yang berdedikasi tinggi sesuai dengan International Maritime Organization (IMO).

D. Teknik Pengumpulan Data

Teknik pengumpulan data dalam penelitian ini menggunakan lembar observasi berupa kuisioner yang diberikan kepada taruna di sekolah Kemaritiman dan Perikanan yang ada di Provinsi Kepulauan Bangka Belitung, yaitu :

1. Angket

Angket yang digunakan adalah angket terstruktur yang diiringi dengan jawaban singkat sehingga mudah mendapatkan informasi yang jelas dan akurat.

2. Wawancara

Pengumpulan data yang sangat sederhana adalah dengan menanyakan langsung kepada para taruna tentang karakter sekolah, faktor yang mempengaruhi sistem pendidikan kemaritiman, dan penyerapan para alumni pada dunia kerja dan industri, baik perikanan maupun pelayaran.Validnya data juga melakukan kunjungan langsung ke Badan Pusat
Statistik(BPS)

Kota

Pangkalpinang/Provinsi, Dinas Tenaga

Kerja, Dinas Kelautan dan Perikanan, serta Dinas Perhubungan

ProvinsiKepulauan Bangka Belitung.

\section{E. Teknik Analisis Data}

Pada penulisan makalah ini, penulis menggunakan instrumen berupa butiran pertanyaan yang diberikan kepada taruna sekolah kemaritiman dengan melakukan tahapan sebagai berikut :

1. Perencanaan

Pada tahapan ini penulis melakukan kegiatan :

a. Penulis merancang kelas pada sekolah yang akan dijadikan sampel.

b. Penulis membuat instrumeninstrumen pertanyaan yang akan digunakan untuk penelitian.

2. Pelaksanaan

Pada tahapan ini, penulis melakukan kegiatan :

a. Penulis memberikan instrumen penelitian kepada taruna NKPI.

b. Penulis melakukan analisis instrumen penelitian.

\section{Evaluasi}

Penulis menganalisis dan mengolah data yang telah dikumpulkan dengan metode instrumen-instrumen pertanyaan. 
4. Pembuatan laporan

Pada tahap akhir ini, penulis menyusun, dan melaporkan hasil penelitian.

\section{III.HASIL PENELITIAN DAN PEMBAHASAN}

Menurut Undang-Undang Republik Indonesia Nomor 20 Tahun 2003 tentang Sistem Pendidikan Nasional Pasal 65, proses sertifikasi kompetensi yang sekarang dilakukan pada akhir tahun pembelajaran ketiga atau keempat perlu dimodifikasi sehingga dapat dilakukan berdasarkan pencapaian kompetensi sesuai dengan tahapan pembelajaran.

Kompetensi Keahlian Nautika Kapal Penangkap Ikan (NKPI) dengan kode 6.1.1 bagian dari kebijakan Direktorat Pembinaan Sekolah Menengah Kejuruan melalui bidang kemaritiman (6), jurusan Pelayaran Kapal Penangkap Ikan (6.1) merupakan panduan struktur kurikulum yang ditujukan kepada sekolah Menengah Kejuruan Kemaritiman dan Perikanan yang berada di bawah naungan Dinas Pendidikan Nasional, Negara Kesatuan Republik Indonesia (NKRI) (Undang-Undang Republik Indonesia Nomor 20 Tahun 2003, BAB1 Pasal 1 Ayat 10, Layanan Pendidikan yang Menyelenggarakan Pendidikan pada Jalur Formal, Non Formal, dan Informal Pada Setiap Jenjang dan Jenis Pendidikan).
Provinsi Kepulauan Bangka Belitung adalah salah satu dari pemerintahan provinsi lainnya yang memiliki tanggung jawab yang besar, khususnya dalam melayani dan membesarkan institusi kemaritiman yang ada, diantaranya sebagai berikut :

1. SMKN 4 Pangkalpinang, yang terletak di Jl. Pasir Ketapang, Kel. Tamberan Kec. Bukit Intan, Kota Pangkalpinang (pada tanggal 19 Agustus tahun 2003 Berdasarkan Surat Keputusan Walikota Pangkalpinang Nomor 227 Tahun 2003 dengan Bidang Keahlian Pelayaran dan Perikanan).

2. SMKN 2 Sungai Liat Bangka, yang terletak di Jl. Sinar Baru, Sungailiat, Kabupaten Bangka.

3. SMKN 1 Tukak Sadai, Jl. Desa Tukak, Kabupaten Bangka Selatan.

Keberadaan SMK Kemaritiman dan Perikanan Provinsi Kepulauan Bangka Belitung (Pendidikan Menengah Terdiri dari Pendidikan Menengah Umum dan Pendidikan Menengah Kejuruan) menjadi gairah baru kepada masyarakat pada umumya untuk mendaftarkan anak mereka masuk dan mengikuti proses pembelajaran disana, karena menjadi suatu kebanggaan tersendiri dengan panggilan yang berbeda dengan sekolah lainnya yaitu bukan siswa melainkan Taruna (KBBI Taruna Adalah Pelajar Sekolah Calon Perwira). 
Dalam membentuk kedisiplinan dan mental kepemimpinan taruna, sekolah kemaritiman mengadakan kegiatan tersebut pada saat sebelum memasuki proses pembelajaran mereka diberikan pelatihan kedisiplinan dengan istilah LDDK (Latihan Dasar Disiplin dan Kepemimpinan), penggemblengan secara fisik terus berlanjut dengan membiasakan diri melakukan latihan fisik ringan, pembinaan mental pengetahuan, dan keterampilan, serta sikap kerja harus selalu ditingkatkan berupa pembentukan mental dan kedisiplinan taruna, serta kepribadian yang seimbang antara usia yang masih remaja dan tanggung jawab yang besar sebagai calon perwira diatas kapal perikanan.

Struktur Kurikulum Kemaritiman telah diterapkan sekolah kemaritiman di Bangka Belitung, yaitu Kurikulum Pendidikan Nasional baik kurikulum tahun 2013 dan kurikulum tahun 2013 revisi, yang mana dapat dikolaborasikan dengan kurikulum yang telah diatur pada peraturan Menteri Perhubungan Nomor KM 9 tahun 2005, tentang Pendidikan dan Pelatihan, Ujian Serta Sertifikasi Pelaut Kapal Penangkapan Ikan, untuk menyikapi keputusan Menteri Tenaga Kerja dan Transmigrasi Republik Indonesia Nomor 298 Tahun 2013 tentang Penetapan Standar Kompetensi Kerja NasionalIndonesia (SKKNI) kategori Perikanan golongan Penangkapan Ikan sub golongan Penangkapan Ikan di Laut
(Undang-Undang Republik Indonesia Nomor 20 Tahun 2003, BAB X Tenang Kurikulum BAB X Pasal 36 Ayat 1).

Latar belakang inilah, mengapa sangat pentingnya sekolah kemaritiman yang belum memiliki manajemen yang telah baku dan terstandarisasi, minimal penerapan Standar Manajemen Mutu (SMM) ISO 9001-2008, ISO 9001 : 2008, berisi standard/elemen yang memungkinkan organisasi/industri dalam melakukan perbaikan yang berkesinambungan (continual improvement) pada yang mana semuanya harus di sesuaikan dengan budaya (culture), hubungan (relationship) dalam tubuh organisasi tersebut, sehingga sistem yang ada akan selalu ter-update dengan kondisi perusahaan dan tuntutan pada era tersebut.

Sisi lain yang sangat perlu diperhatikan oleh setiap sekolah kemaritiman adalah sarana dan prasarana yang sesuai dengan standar KM Nomor 9 Tahun 2005 tentang Penyelenggaraan Ujian Sertifikasi Kepelautanyang harus dilengkapi sebagai acuan minimal taruna dapat melakukan praktik di sekolah.

Dalam kunjungan kerjanya Gubernur Provinsi Kepulauan Bangka Belitung, Bapak Erzaldi Rosman Djohan, beliau mengatakan bahwa SMK Negeri 4 atau SMK Pelayaran ini adalah satu satunya sekolah pelayaran di Bangka Belitung, namun dirinya mengakui setelah peninjauan tersebut terlihat fasilitas- 
fasilitasbaik yang kurang memadai, baik itu ruang yang rusak, maupun fasilitas pembelajaran yang rusak dan tidak lengkap. Hal ini membuat Gubenur tidak optimis bahwa sekolah ini akan maju ke dalam LKS SMK (Gubernur Babel Sidak SMK Negeri 4 PangkalpinangSenin 18 December 2017,https://www.republika.co.id/berita/nasi onal/daerah/17/12/18/p15u4f283-gubernurbabel-sidak-smkn-4-pangkalpinang).

Kita semua menyadari, pada proses pembelajaran dibutuhkan keseimbangan antara jumlah peserta didik dengan perlengkapan sarana dan prasarana praktik siswa di sekolah ini merupakan tanggung jawab pemerintah daerah, dan dengan harapan dapat direalisasikan pada waktu yang sudah direncanakan pemerintah sesuai dengan permohonan anggaran yang ada pada pemerintah Provinsi Kepulauan Bangka Belitung. Faktor utama lainnya pada pengelolaan sekolah kemaritiman adalah mengembangkan potensi berbahasa asingtaruna dan agensi yang memiliki legalitas (Undang-Undang Republik Indonesia Nomor20 Tahun 2003, Bab VII, Bahasa Pengantar Pasal 33 Ayat 3, Bahasa Asing Dapat Digunakan Sebagai Bahasa Pengantar Pada Satuan Pendidikan Tertentu Untuk Mendukung Kemampuan Berbahasa Asing Siswa), serta jaringan pasar kerja (Dunia usaha dan industri) nasional dan internasional belum dikelola dengan secara maksimal baik di sekolah dalam menciptakan sumberdaya manusia yang utuh dan kurangnya sinergi komunikasi antar dinas terkait diantaranya, Dinas Pendidikan,Dinas Tenaga Kerja, Dinas Perhubungan, Dinas Kelautan dan Perikanan, serta Badan Pusat Statistik Provinsi Kepulauan Bangka Belitung (Kadin Pendidikan Babel mengatakan minimnya data lulusan SMK ini melaporkan atau menginformasikan ke sekolah atau Dinas Pendidikan yang masih kurang, http://m.radarbangka.co.id/berita/detail/sung ailiat/43424/babel-data-lulusan-smk).

Sisi lain yang perlu diperhatikan adalah keberadaan usaha perikananyang ada di Provinsi Kepulauan Bangka Belitung, apakah bisa menyerap para alumni SMK Kemaritiman yang setiap tahunnya selalu bertambah, ketidak jelasan data alumni pada Badan Pusat Statistik (BPS) dan Dinas Tenaga Kerja Provinsi Kepulauan Bangka Belitung mengenai penyerapan tenaga kerja yang siap pakai, siap kerja, dan siap untuk menjadi seorang perwira diatas kapal.

Kepedulian membangun generasi muda sebagai penerus bangsa adalah tanggung jawab kita semua, semoga makalah ilmiah ini dapat memberikan masukan yang positif kepada Pemerintahan Provinsi Kepulauan Bangka Belitung untuk menyikapi dan memudahkan penyerapan tenaga kerja profesional berdaya saing global kepada putra-putri kita. Aamiin. 


\section{KESIMPULAN}

Berdasarkan uraian dalam pembahasan, dapat disimpulkan bahwa problematika menciptakan calon perwira kapal penangkap ikan begitu kompleks dan perlu diperhatikan seluruh stakeholder mengenai fasilitas, peralatan praktik siswa, dan agensi perusahaan perikanan bidang tangkap serta orangtua taruna itu sendiri untuk memberikan dan/atau mendapatkan informasi seluas-luasnya dari dinas terkait.

Merupakan kewajiban kita bersama dalam mengelola, membina, dan mengatur regulasi ketenagakerjaan, serta kebijakan pemerintahan daerah untuk membukaseluasluasnya pemahaman kepada para alumni kemaritiman untuk semakin sadar bahwa mereka sangat diperhatikan dan dibutuhkan dalam pengembangan sumberdaya manusia profesional di negeri ini.

Sinergi ini sangat perlu dipertimbangkan dan dapat membuka nuansa kebersamaan sebagai pilot project kedepan dalam koordinasi yang satu, tujuan yang mulia, menciptakan generasi muda calon perwira diatas kapal perikanan yang berkompeten, memiliki dedikasi tinggi, dan memiliki dokumen keahlian dan keterampilan yang sesuai dengan aturan yang berlaku di Direktorat Jenderal Perhubungan Laut, serta pengelolaan agensi yang memiliki legalitas di Dinas Tenaga Kerja Provinsi Kepulauan Bangka Belitung.
Semoga ini semua menjadi amal bakti kita kepada negara ini, khususnya Provinsi Kepulauan Bangka Belitung dalam mencetak generasi "EMAS MILENIAL”yang diidamkan oleh kita semua sebagai negara maju, berkompetensi tinggi, memilki dedikasi ketimuran yang selalu mengatakan "KITA BISA" menghadapi ini semua, Aamiin.

\section{DAFTAR PUSTAKA}

(1) ...(2008). Materi Ajar Mata Kuliah Tata Tulis Karya Ilmiah. TPB-ITB, Bandung

(2) Basir. (2012). Strategi Pengembangan SMK Pelayaran Perikanan. (http://bangka.tribunnews.com/2012/09/ 20/strategi-pengembangan-smkpelayaran-dan-perikanan?page $=1$ )

(3) BPS (230300419).(2017). Keadaan Angkatan Kerja Provonsi Kepulauan BangkaBelitung.Badan Pusat Statistik Provinsi Kepulauan Bangka Belitung (https://babel.bps.go.id)

(4) Elvian, Akhmad. (2002).Pangkalpinang Kota Kenangan. Dinas Kebudayaan, Pariswisata, Pemuda dan Olahraga Kota Pangkalpinang.

(5) Undang-Undang Republik Indonesia Nomor 20 Tahun2003 Tentang Sistem Pendidikan Nasional. Lembar Negara Republik Indonesia Tahun 2003. Jakarta.

(6) Peraturan Menteri Perhubungan Republik Indonesia Nomor KM 9 Tahun 
2005 Tentang Pendidikan dan Pelatihan ujian standar sertifikasi Pelaut Kapal Penangkap Ikan. Jakarta.

(7) Lampiran Keputusan menteri Tenaga Kerja dan Transmigrasi Nomor 298 Tahun 2013Tentang Penetapan Standar Kompetensi Kerja Nasional Indonesia Golongan Pokok Golongan Perikanan, Golongan Penangkapan Ikan Sub Golongan Penangkapan Ikan di Laut. Jakarta. 